\title{
Are there Childhood Major Depressive Disorder Genetic Markers and Mutations?
}

\author{
Nayana Marques Vidal', Kaline Cristh Rabelo Nobre', \\ Antonio Gilvan Teixeira Júnior ${ }^{1}{ }^{2}$ \\ Izabella Bárbara Quirino de Lima ${ }^{2},{ }^{3}$ \\ Modesto Leite Rolim-Neto ${ }^{1}$
}

\section{Abstract}

Background: There are many challenges in the childhood psychopathology field to carry out epidemiological studies. The child is a being in evolution with behavioral changes, making more difficult to conduct this kind of research. Even nowadays, there are still several diseases being treated as they were all the same, such as disorders, disturbances, and behavioral changes. Moreover, there are still difficulties regarding the parameterized diagnostic criteria, such as the points awarding cut-off scales utilization and the questionnaires application.

Objective: To identify whether are genetic changes that can cause childhood major depressive disorder and if there are genetic markers that can be used to detect these changes.

Results: Studies showed a strong relationship between environmental stress (whether emotional or physical) and the genetic pool that each individual has as specific genes regulating serotonergic and neurotrophic circuits. The pathophysiology and the interaction of these circuits are not well established, but studies confirm their interactions and expression with depression.

Conclusion: Major Depressive Disorder (MDD) is a deeply familiar disorder, with genetic influences not very well established and relevant environmental components.

CoutinHo, et al (2014) reported according to different regional/local researches that the prevalence of major depressive disorder (MDD) in
1 Faculty of Medicine, Federal University of Cariri (UFCA). Barbalha, Ceará, Brazil.

2 Science without Borders (CSF) fellow at University of Liverpool (UoL). Liverpool, United Kingdom.

3 Institute of Biological Sciences, Federal University of Minas Gerais (UFMG), Belo Horizonte, Minas Gerais, Brazil.

Contact information:

Modesto Leite Rolim-Neto.

” modestorolim@yahoo.com.br

Keywords

Childhood; Major Depressive Disorder; Genetic Markers; Mutations. 
Brazil in children and adolescents is estimated about $3.55 \%$ to $45.7 \%$ of this population, and the higher percentage was found in the Southeast. During childhood, practically there is no sexual difference sexual between the genders, with the male-female ratio $1: 1$. On the other hand, in adolescents, the prevalence was higher than in females, 1:2.

The risk of MDD increases with the age, reaching $20 \%$ at 18 years-old. Psychiatric diseases usually present associated with other diseases and depending on the studied reference, $14 \%$ to $39 \%$ of young people have a depressive disorder in association with another psychiatric disease. The most common associated diseases with depression are the anxiety disorder, followed by disruptive behavior, attention deficit hyperactivity disorder (ADHD) and substance use disorder (CIVIDANES et al, 2014).

MDD is a deeply familiar disorder, with genetic influences not very well established and relevant environmental components. The environmental interference includes dysfunctional families, paternal figure change, parent loss, physical abuse, negligence, social isolation, social support absence, domestic and community violence exposure, and low socioeconomic status (LUBY et al., 2014; SLAVICH et al, 2014).

LUBY et al, (2014), evaluated the relationship between the Preschool Depression Syndrome (PDS), usually occurring in children from 3 to 6 years old, and the development of MDD at ages above 6 years and in adolescents; They concluded that PDS is an important risk factor associated mainly with one or more of the aforementioned situations.

The depressive disorder pathophysiological mechanisms have not been fully elucidated yet. They are multifactorial, as already described, and have biological, environmental and genomic components. SLAVICH et al, (2014), argue that interpersonal stress and social rejection can act as biological reactions trigger, promoting changes in the immune system, leading to inflammation and therefore the proinflammatory cytokines production. These cytokines, in turn, promote behavioral changes such as social isolation, fatigue, sad mood, psychomotor retardation, among others.

After performing studies with the human genome, WILson et al, (2014) argue that most psychiatric disorders are strongly heritable, although the degree of this genetic influence is not yet known.

In the last decade, the genetic and environmental interaction identification has led to an intense debate aiming to clarify the limits of this interaction. Rocha et al. (2015) tested if the relationship between childhood maltreatment and a subsequent depressive episode was influenced by the 5-HTTLPR genotype. This study suggests that the aforementioned genotype has an important role in the relation between the abuse in childhood and the subsequent episodes of depression in youth.

Gutierrez et al, (2015) highlight the genetic and childhood maltreatment role as risk factors for MDD development. Childhood maltreatment experiences are related to mental disorders, possibly with specific gene effects influencing and stimulating the initial traumatic event.

Results confirm the MDD increased risk due to childhood maltreatment is modified by the variation of both genes SERT and BDNT. The individual evaluation of these genes with maltreatment showed no relevance. The three-way action (environment vs. gene 1 vs. gene 2) had the higher influence in the adulthood MDD development (GUTIERREZ et al., 2015).

Individuals carrying both the SERT/S allele as BDNF/Met allele seem to be the most vulnerable group to the childhood maltreatment impacts and the depression development both in adults and in adolescents. The BDNF presence with only one Met+ allele was statistically related to refractory cases progressing to MDD. (Gutierrez et al, 2015; Kudinova et al, 2015; Frodl et al, 2014; Cross-Fuentes et al, 2014.).

MDD development both in adolescence and in adulthood depends on the interaction between the environment (represented by the trauma developed during childhood) and the complex interaction of a 
high plasticity genes number (Gutiérrez et al., 2015; Kudinova et al., 2015; Frodl et al., 2014; Cruz-Fuentes et al., 2014).

PeYrot et al., (2014) describe the polygenic risk score presence as a group of genes that would act together predisposing psychiatric diseases, particularly MDD. It reveals that direct genetic effects are greater in the presence of childhood trauma, but individuals with high polygenic risk score are the most vulnerable groups to depressogenic effects in childhood.

Increased exposure to serious adverse disorders in childhood have been linked to smaller sizes of leukocytes telomeres in adults, suggesting accelerated cellular aging. Serious physical or emotional disorders in childhood cause biological sequelae leading to the shortening of telomeres and premature cell aging which predisposes to the development of the major depressive disorder (CHEN et al., 2014; GotLIB et al., 2014). Table 1 abstracts some results of the cited studies on the interaction between gene and environment.

High-risk familiar groups also have hormonal disturbances related to the hypothalamic-pituitaryadrenal axis. Depressed mothers' children have shorter telomeres than non-depressed mothers'. In addition to their greater stress with increased serum levels of cortisol (Foland-Ross et al., 2014; Gotlib et al., 2014).
Studies suggest structural changes in the left hippocampus and in the dentate gyrus may be present before the depression onset in adults, during adolescence, and such changes are correlated with the 5-HTTLPR gene and depression presence. These structural findings are important as markers and they can indicate the most susceptible groups (LITTLE et al., 2014; FrodL et al., 2014).

MDD in childhood goes beyond social and psychological issues and may also be involved in the development of organic pathologies. MDD in childhood is not associated with a good cardiovascular profile with a risk of cardiovascular disease in adolescence. Treatment and early identification of vulnerable groups for MDD in childhood can be a strategy to reduce the cardiovascular disease incidence in adults (Rottenberg et al., 2014).

Still aiming to associate specific genes with the presence of mood disorders and suicidal behavior, Muluins et al. (2014) conducted a cohort study evaluating the German and English studies data of patients who had been previously assessed for common genetic variation in these two aforementioned pathologies. However, in the end of the study, there were not enough evidence to support their hypothesis, the existence of a common gene to these two diseases.

Studies showed a strong relationship between environmental stress (whether emotional or physi-

Table 1. Studies on the interaction between gene and environment.

\begin{tabular}{|c|c|}
\hline Studies & Results \\
\hline $\begin{array}{l}\text { Rocha, et al., (2015) } \\
\text { American Journal Of Psychiatry }\end{array}$ & $\begin{array}{l}\text { The relationship between abuse in childhood and subsequent depressive episode } \\
\text { were influenced by the } 5 \text {-HTTLPR genotype. }\end{array}$ \\
\hline $\begin{array}{l}\text { Gutiérrez et al., (2015) } \\
\text { Journal Of Psychiatry \& Neuroscience }\end{array}$ & $\begin{array}{l}\text { Individuals who carry both the SERT S allele and the BDNF Met allele showed to be } \\
\text { the most vulnerable group to the impact of childhood maltreatment and depression } \\
\text { development. }\end{array}$ \\
\hline $\begin{array}{l}\text { Peyrot, ET al.,(2014) } \\
\text { The British Journal Milaneschinal Of } \\
\text { Psychiatry }\end{array}$ & $\begin{array}{l}\text { Describes polygenic risk score as a vulnerability factor for groups exposed to the } \\
\text { depressant effects in childhood. }\end{array}$ \\
\hline $\begin{array}{l}\text { Chen, et al., (2014) } \\
\text { Journal Of Affective Disorders }\end{array}$ & $\begin{array}{l}\text { Relates the smaller size of the telomeres with exposure to serious adverse disorders } \\
\text { in childhood, MDD predisposition in prone adults. }\end{array}$ \\
\hline $\begin{array}{l}\text { Gotlib, et al.,(2014) } \\
\text { Molecular Psychiatry }\end{array}$ & $\begin{array}{l}\text { Depressed mothers' children have shorter telomeres than non-depressed mothers' } \\
\text { children and they also have higher stress with increased cortisol levels. }\end{array}$ \\
\hline
\end{tabular}


cal) and the genetic pool that each individual has as specific genes regulating serotonergic and neurotrophic circuits. The pathophysiology and the interaction of these circuits are not well established, but studies confirm their interactions and expression with depression.

The social importance of these studies alerts and awakes professionals, researchers, and caregivers since they highlight the relevance of having a holistic view regarding the patient care, taking into account the past and the current biological context in order to understand the disease.

\section{References}

- Chen S. H., Epel E. S., Mellon S. H, Lin J., Reus V. I, Rosser R., et al. Adverse childhood experiences and leukocyte telomere maintenance in depressed and healthy adults. Journal of Affective Disorders, 2014, 169,: 86-90.

- Cividanes, G., Mello A. F., Sallum J. M., Fossaluza V., Medeiros M. et al. Lack of association between the 5-HTTLPR and positive screening for mental disorders among children exposed to urban violence and maltreatment. Rev. Bras. Psiquiatr., 2014, 36 (4):277-284

- Coutinho M. P. L., Oliveira M. X., Pereira D. R., Santana I. O. Indicadores psicométricos do Inventário de Depressão Infantil em amostra infanto-juvenil. Aval. psicol., 2014, 13(2): , 269-276,

- Cruz-Fuentes, C.S., Benjet C., Inez-Levy G.A.M., Perez-Molina A. Briones-Velasco M., e Suarez-Gonzalez J. BDNF Met66 modulates the cumulative effect of psychosocial childhood adversities on major depression in adolescents. Brain Behav, 2014, 4(2):.290-297.

- Foland-Ross, L.C., Kircanski K., E Gotlib I.H. Coping with having a depressed mother: The role of stress and coping in hypothalamic-pituitary-adrenal axis dysfunction in girls at familial risk for major depression. Dev Psychopathol, 2014, 26(42):1401-1409.

- Frodl T., Skokauskas N., Frey E.M., Morris D.,Gill M., e Carballedo A. BDNFVal66Met genotype interacts with childhood adversity and influences the formation of hippocampal subfields. Human Brain Mapping, 2014, 35(12):5776-5783.

- Gotlib, I.H., LeMoult J., Colich N.L ., Foland-Ross L.C., Hallmayer J., Joormann J., Lin J., e Wolkowitz O.M. Telomere length and cortisol reactivity in children of depressed mothers. Molecular Psychiatry, 2014, 20(5):615-620.

- Gutiérrez B., Bellón J.A., Rivera M., Molina E.,King M., et al. EN. Journal Of Psychiatry \& Neuroscience, 2015, 40(3):187-196.

- Kudinova A. Y., McGeary J.E., Knopik V.S., Gibb B.E. Brain derived neurotrophic factor (BDNF) polymorphism Moderates the interactive effect of 5-HTTLPR polymorphism and childhood abuse on diagnoses of major depression in women. Psychiatry Research, 2015, 225(3):746-747.
- Little K., Olsson C.A ., Whittle S., Youssef1 G.J., Byrne M;L., Simmons J.G., Yücel M., Foley D.L. e Allen N.B. Association between serotonin transporter genotype, brain structure and adolescent-onset major depressive disorder: a longitudinal prospective study. Translational Psychiatry, 2014, 4(9):1-8.

- Luby, J. L., Gaffrey M. S., Tillman R. M. S., April L. M., e Belden A.C.

- Trajectories of Preschool Disorders to Full DSM Depression at School Age and Early Adolescence: Continuity of Preschool Depression. American Journal Of Psychiatry, 2014, 171(7):768776.

- Mullins N., Perroud N., Uher R., Butler A.W., Cohen-Woods S., Rivera M.,et al. Genetic relationships between suicide attempts, suicidal ideation and major psychiatric disorders: A genomewide association and polygenic scoring study. Am. J. Med. Genet., 2014, 165(5):428-437.

- Peyrot W. J., Y., Abdellaoui A., Sullivan P. F., Horttega J. J., Boomsma D. I., Penninx B. W. J. H. Effect of polygenic risk scores on depression in childhood trauma. The British Jour Milaneschinal Of Psychiatry, 2014, 205(2):113-119.

- Rocha T.B.M., Hutz M.H., Oliveira A.S.,Genro J.P., et al. GeneEnvironment Interaction in Youth Depression: Replication of the 5-HTTLPR Moderation in a Diverse Setting. American Journal Of Psychiatry, 2015,172(10): 978-985.

- Rottenberg J.,Yaroslavsky I., Carney R.M., Freedland K. M., George C.J., et al. The Association Between Major Depressive Disorder in Childhood and Risk Factors for Cardiovascular Disease in Adolescence. Psychosomatic Medicine, 2014, 76(2):122-127.

- Slavich G. M., Irwin M.R. From stress to inflammation and major depressive disorder: A social signal transduction theory of depression. Psychological Bulletin, 2014, 140(3):774-815.

- Wilson S., Vaidyanathan U., Miller M. B., McGue M., e lacono W.G.

- Premorbid risk factors for major depressive disorder: Are they associated with early onset and recurrent course?. Dev Psychopathol, 2014, 26(42): 1477-1493.

\section{Publish in International Archives of Medicine}

International Archives of Medicine is an open access journal publishing articles encompassing all aspects of medical science and clinical practice. IAM is considered a megajournal with independent sections on all areas of medicine. IAM is a really international journal with authors and board members from all around the world. The journal is widely indexed and classified Q2 in category Medicine. 